\title{
Children with visual impairments may have altered joint movement: an observational case-control study
}

\author{
Crianças com deficiência visual podem ter a amplitude de movimento \\ articular alterada: um estudo observacional tipo caso-controle \\ Niños con deficiencia visual pueden tener la amplitud de movimiento \\ articular alterada: un estudio observacional tipo caso-control
}

Silvia Maria Amado João', Michelle de Pádua², Ulisses Tirollo Taddei³ ${ }^{3}$ Yuri Carvalho Mendes³ Juliana Ferreira Sauer ${ }^{2}$

\begin{abstract}
I To assess the articular range of motion in children with congenital visual impairment. Were evaluated 75 children between five and twelve years old, 49 with normal visual acuity and 26 visually impaired. Two evaluators performed the measure of active and passive range of motion by goniometry of shoulder and hip in all axes of motion. All examiners made a test of correlation between data obtained, to determine the inter-rater reliability, using the intraclass correlation coefficient (ICC). In individuals with visual impairments was statistically significant difference, with higher range of motion in individuals with visual impairments to medial and lateral rotation of shoulder and hip lateral rotation. Were found: high correlation in the inter-rater reliability (ICC>0.70) for 9 (22.5\%) groups of articular range of motion, moderate correlation (0.7>ICC>0.5) for 25 (62.5\%) groups and low correlation to 6 (15\%) groups ranges of motion. Sampled children with congenital visual impairment showed greater joint mobility for rotational range of motion of the shoulder and hip than children with normal visual acuity, although they have also shown lower values for articular range of motion in abduction and extension in shoulders.
\end{abstract}

Keywords | Child; Visually Impaired Persons; Range of Motion, Articular.
RESUMOI Avaliou-se a amplitude de movimento articular em crianças com deficiências visuais congênitas. Foram avaliadas 75 crianças entre 5 e 12 anos de idade, sendo 49 com acuidade visual normal e 26 portadoras de deficiência visual. Dois avaliadores realizaram a medida da amplitude de movimento articular ativa e passiva, pela goniometria do ombro e quadril, em todos os eixos de movimento. Todos os avaliadores realizaram um teste de correlação entre os dados obtidos, para determinação da confiabilidade interavaliador, por meio do coeficiente de correlação intraclasse (ICC). Nos indivíduos com deficiência visual houve diferença estatisticamente significativa, com maiores valores de amplitude de movimento para rotação medial e lateral de ombro e rotação lateral de quadril. Foram encontradas: alta correlação na confiabilidade interexaminador (ICC>0,70) para 9 (22,5\%) grupos de amplitude de movimento articular, correlação moderada $(0,7>\mid C C>0,5)$ para 25 (62,5\%) grupos e baixa correlação para 6 (15\%) grupos de amplitudes de movimento. As crianças amostradas com deficiência visual congênita apresentaram maior mobilidade articular para as amplitudes de movimento rotacional do ombro e quadril que as crianças sem comprometimentos visuais, embora tenham apresentado também menores valores para amplitude de movimento articular de abdução e extensão de ombros.

Descritores I Criança; Pessoas com Deficiência Visual; Amplitude de Movimento Articular.

\footnotetext{
Study carried out at the Musculoskeletal Assessment Laboratory of the Physical Therapy, Speech Language Therapy and Occupational Therapy Department from the Medical School of Universidade de São Paulo (USP ) - São Paulo (SP), Brazil. 'Professor and PhD in the Physical Therapy Course of the Medical School at USP - São Paulo (SP), Brasil. ${ }^{2}$ Physical Therapist; Master's degree by the Post-graduate Program of Rehabilitating Sciences from the Medical School of USP - São Paulo (SP), Brazil.

${ }^{3}$ Physical Therapist graduated by USP - São Paulo (SP), Brazil.
} 
RESUMEN I Se evaluó la amplitud de movimiento articular en niños con deficiencias visuales congénitas. Se evaluaron a 75 niños con edades entre 5 y 12 años, siendo 49 con acuidad visual normal y 26 con deficiencia visual. Dos evaluadores realizaron la medición de la amplitud de movimiento articular activa y pasiva mediante goniometría del hombro y de la cadera, en todos los ejes de movimiento. Todos los evaluadores realizaron un test de correlación entre los datos obtenidos para la determinación de la fiabilidad interevaluador, por medio del coeficiente de correlación intraclase (ICC). En los individuos con deficiencia visual hubo diferencia estadísticamente significativa, con mayores valores de amplitud de movimiento para la rotación medial y lateral del hombro y rotación lateral de la cadera. Fueron encontradas: alta correlación de fiabilidad interevaluadores (ICC>0,70) para 9 (22,5\%) grupos de amplitud de movimiento articular, correlación moderada $(0,7>\mid C C>0,5)$ para 25 (62,5\%) grupos y baja correlación para 6 (15\%) grupos de amplitudes de movimiento. Los niños incluidos en la muestra con deficiencia visual congénita presentaron mayor movilidad articular para las amplitudes de movimiento de rotación del hombro y de la cadera que los niños sin deficiencias visuales, aunque también presentaron valores más bajos para la amplitud de movimiento articular de abducción y extensión de hombros.

Palabras clave I Niño; Personas con Deficiencia Visual; Amplitud de Movimiento Articular

\section{INTRODUCTION}

Vision plays an essential role in the development of the body, being a primary source of stimuli that enable the direct relationship between the individual and the external environment ${ }^{1,2}$. This relationship is represented by the ability to move and explore the environment, thus determining the acquisition of essential experiences that enable the global development and the adaptation to the environment ${ }^{3}$.

Several studies have been trying to find relationships between the incidence of visual impairment and anthropometric changes in the affected population ${ }^{4-7}$, which are often motivated by the stereotyped posture that is present in some of these individuals or by the mannerisms that can be a result of poor motor development during childhood, usually associated with imperfect or absent visual stimuli ${ }^{8,9}$.

Other studies try to correlate such observations with the static posture ${ }^{10,11}$, or to correlate posture to functional tasks ${ }^{12}$ and gait ${ }^{13}$. Bouchard e Tétreault ${ }^{2}$ found that children with visual impairment presented with poorer and weaker motor skills and, in order for their movements to be functional, they would tend to change the way they performed several tasks. This study also described the decreased range of motion involving rotations, however, with no experimental confirmation, which could be related to the poor repertoire acquired during motor development.

Changes in the joint range of motion may cause alterations in the development of the musculoskeletal system of the children; especially when considering the transition period to adolescence, in which severe physical and structural changes happen ${ }^{14,15}$. Besides, it should be considered that children have higher values of range of motion in comparison to adults, and they can also present with benign hypermobility in childhood, which affecs 5 to $30 \%$ in the populations ${ }^{16}$.

According to the Brazilian Institute of Geography and Statistics (IBGE), in 2000, 14\% of the Brazilians had some type of visual impairment, and, out of these, $57 \%$ had a permanent difficulty to see; nowadays, it is the most incident visual impairment in Brazil ${ }^{17}$.

The objective of this study was to compare the joint range of movement in children aged 5 to 12 years old with blindness and congenital low vision with asymptomatic controls.

The hypothesis is that children with visual impairment during development will present with lower values of joint range of movement.

\section{METHODOLOGY}

Male and female children, aged from 5 to 12 years old, attending the institutions Escola Júlio Mesquita, Instituição Padre Chico, Associação Brasileira de Assistência ao Deficiente Visual and patients assisted by the Sector of Sub-Normal Vision of Hospital das Clínicas, in São Paulo. Children who presented with neuromuscular, musculoskeletal and cardiorespiratory diseases were excluded ${ }^{18}$.

All of the participants were contacted by educational institutions that were interested to participate in the study, or families were contacted by telephone. An assessment report was offered to each one of the participants after the study was concluded. 
The participation of the children depended on the parents or parties in charge signing the Informed Consent Form. The study was approved by the Research Ethics Committee of Hospital das Clínicas, in the Medical School of Universidade de São Paulo (CAPPesq).

Participants formed two groups: the control group (CG), composed of individuals with no visual alterations, and the experimental group (EG), composed of children with visual impairment caused by congenital, infectious, genetic or parasitic disorders, which would lead the visual capacity to be higher than $70 \%$ with the best correction, that is, low vision.

The dysfunctions included in the study for the EG approach the disorders that affect the sampled population the most $^{8}$, being retinal or refraction problems, abnormality in crystalline lens or oculomotor pathologies.

In the CG, there were 49 children with mean age of $8.8 \pm 1.5$ years old, being 25 male and 24 female participants, with mean weight of $30.5 \pm 11.5 \mathrm{~kg}$, mean height of $1.3 \pm 0.2 \mathrm{~m}$, mean body mass index (BMI) of $17.5 \pm 4.7 \mathrm{~kg} / \mathrm{m}^{2}$; in the EG, there were 26 children with mean age of $8.4 \pm 2.4$ years old, 12 male and 14 female participants, with mean weight of $31.5 \pm 8.7 \mathrm{~kg}$, mean height of $1.3 \pm 0.1 \mathrm{~m}$, mean BMI of $17.2 \pm 3.1 \mathrm{~kg} / \mathrm{m}^{2}$, with visual impairment.

Goniometry was conducted by a universal goniometry by $\mathrm{Carci}^{\circledR}$, according to the methodology described by Marques $^{19}$ for flexion, extension, abduction, lateral rotation and medial rotation movements in shoulder and hip joints, actively and passively, with participants wearing bathing suits (speed or bikini).

Measurements were taken by two different examiners, in order to ensure the reliability of the values. Inter-rater reliability was calculated by the intraclass correlation coefficient (ICC). Measurements were taken on two different days, so that the result from the first measurement would not influence the next one.

\section{Statistics}

The software Statistica 8.0 was used, and the ShapiroWilk test was conducted to verify data normality. Afterwards, the Student's $t$-test was performed for independent variables, in order to assess the differences in mean values of joint motion between the $\mathrm{CG}$ and the EG, with $\alpha=0.01$.

By using the ICC, measurements from both evaluators were compared to determine inter-rater reliability.
ICC values of 0.00 to 0.25 were classified as little or no reliability; low reliability comprised values from 0.26 to 0.49 ; moderate reliability, from 0.50 to 0.69 ; high reliability, from 0.70 to 0.89 ; and very high reliability, for values that were higher than $0.90^{20-22}$.

\section{RESULTS}

Values concerning the range of movement of passive and active medial shoulder rotation are shown in Table 1 . There was a significant difference $(p<0.01)$ between the EG and the $\mathrm{CG}$, and range values are higher in the EG.

For the hip range of motion, movements that presented statistically significant differences in the Student's t- test were the passive lateral rotations and the passive left hip medial rotation, as observed in Table 2.

In inter-rater reliability, the ICC found: high reliability in 9 groups (22.5\%), moderate reliability in 25 groups $(62.5 \%)$ and low reliability in 6 groups $(15 \%)$.

Table 1. Mean, standard-deviation and comparison between groups for movements of medial rotation, lateral rotation, abduction, flection and extension of the shoulder, passively and actively, for the right and left upper limb

\begin{tabular}{lccl} 
Shoulder & \multicolumn{2}{c}{ Mean \pm standard-deviation } & \\
\cline { 2 - 3 } movements & CG & EG & \\
PRMR & $69.51 \pm 09.82$ & $93.15 \pm 17.61$ & $0.00^{*}$ \\
PLMR & $72.45 \pm 12.11$ & $88.38 \pm 15.79$ & $0.00^{*}$ \\
ARMR & $57.71 \pm 12.09$ & $78.38 \pm 15.82$ & $0.00^{*}$ \\
ALMR & $62.08 \pm 12.75$ & $79.38 \pm 17.25$ & $0.00^{*}$ \\
PRLR & $125.02 \pm 08.45$ & $118.00 \pm 18.53$ & 0.02 \\
PLLR & $122.82 \pm 08.89$ & $116.46 \pm 20.27$ & 0.06 \\
ARLR & $117.76 \pm 10.03$ & $113.15 \pm 13.74$ & 0.10 \\
ALLR & $111.91 \pm 10.15$ & $106.50 \pm 13.87$ & 0.05 \\
PRAb & $178.86 \pm 07.24$ & $174.92 \pm 09.62$ & 0.05 \\
PLAb & $177.59 \pm 08.36$ & $174.08 \pm 14.27$ & 0.18 \\
ARAb & $178.08 \pm 12.18$ & $171.15 \pm 16.38$ & 0.04 \\
ALAb & $176.86 \pm 07.71$ & $169.08 \pm 17.06$ & $0.00^{*}$ \\
PRF & $172.49 \pm 07.19$ & $171.69 \pm 11.09$ & 0.70 \\
PLF & $175.10 \pm 06.44$ & $170.00 \pm 10.55$ & 0.01 \\
ARF & $169.10 \pm 08.52$ & $164.69 \pm 14.31$ & 0.09 \\
ALF & $172.28 \pm 07.80$ & $168.23 \pm 11.34$ & 0.07 \\
PREx & $89.79 \pm 08.29$ & $83.69 \pm 11.81$ & 0.01 \\
PLEx & $93.55 \pm 08.38$ & $86.77 \pm 11.65$ & $0.00^{*}$ \\
AREx & $70.73 \pm 09.80$ & $69.38 \pm 12.58$ & 0.60 \\
ALEx & $71.43 \pm 10.45$ & $69.23 \pm 11.31$ & 0.40 \\
\hline Stats & $5 \pm 0$ &
\end{tabular}

*Statistically significant in the Student's t-test; MR: medial rotation; LR: lateral rotation; Ab: abduction; F: flection; Ex: extension; P: passive; A: active; R: right; L: left; CG: control group; EG: Study group 


\section{DISCUSSION}

The objective of this study was to observe possible changes in the joint range of motion among children with visual impairment. Data show that children with visual impairment presented increased hip and shoulder range of motion, when compared to children at the same age group with no visual impairment.

According to Decree n. 5,296, from December 2 ${ }^{\text {nd }}$, 2004, the person characterized with blindness is the one with visual acuity similar to or lower than 0.05 in the best eye, with the best optical correction; low vision consists of visual acuity between 0.3 and 0.05 in the best eye, also with the best optical correction, and in cases when the sum of the visual field measurement in both eyes is equal to or lower than $60^{\circ}$, or the simultaneous occurrence of any of the previous conditions.

It is possible that the use of rotational movements during childhood for visual impaired children is higher due to the need to discover the environment around them in an alternative way ${ }^{23}$, therefore, they are more developed during maturation.

Gaunet et al..$^{24}$ reported that early blindness affects both exploratory patterns and the performance of individuals, by interacting with objects disposed in a space, when compared to blind-folded individuals.

As previously described, it was expected that individuals with imperfect or absent visual acuity had differences concerning functional repertoire in their motor development, which would result in possible biomechanical changes. Results differed from the expected as to the form of these differences, since the hypothesis was that individuals with such impairment would obtain lower values of range of motion, which is exactly the opposite of what was found.

Another effect that would possibly lead to the obtained results would be sampling-related problems, once most individuals in the EG were institutionalized and participated in numberless extracurricular tasks, such as physical activities, musical education, arts, among others. Children in the CG were not stimulated nor did they have the access offered by the school to the same activities.

In order to verify this last possibility, the precision of comparisons between groups was decreased between groups. The expectation was that, in case the affirmative was true, higher values of range of motion would be higher in the EG than in the CG.

For non-rotational shoulder movements, significantly different values were obtained between groups
Table 2. Mean, standard-deviation and comparison between groups for movements of medial rotation, lateral rotation, abduction, flection and extension of the shoulder, passively and actively, for the right and left lower limb

\begin{tabular}{lccc} 
Hip & \multicolumn{2}{c}{ Mean \pm Standard-deviation } & \\
\cline { 2 - 3 } movements & CG & EG & -value \\
\cline { 2 - 3 } PRLR & $32.57 \pm 05.98$ & $44.77 \pm 06.35$ & $0.00^{*}$ \\
PLLR & $34.69 \pm 06.98$ & $44.08 \pm 09.34$ & $0.00^{*}$ \\
ARLR & $27.10 \pm 05.49$ & $31.08 \pm 10.22$ & 0.03 \\
ALLR & $29.51 \pm 07.07$ & $33.31 \pm 09.03$ & 0.04 \\
PRMR & $44.94 \pm 06.20$ & $49.54 \pm 10.20$ & 0.01 \\
PLMR & $43.96 \pm 06.03$ & $50.23 \pm 08.71$ & $0.00^{*}$ \\
ARMR & $33.24 \pm 06.16$ & $37.23 \pm 09.12$ & 0.58 \\
AEMR & $34.20 \pm 06.57$ & $37.23 \pm 09.34$ & 0.10 \\
PRF & $79.14 \pm 07.81$ & $76.62 \pm 09.39$ & 0.21 \\
PLF & $81.76 \pm 06.79$ & $76.85 \pm 09.23$ & 0.01 \\
PREX & $21.06 \pm 04.30$ & $23.54 \pm 05.81$ & 0.03 \\
PLEX & $20.89 \pm 04.08$ & $23.62 \pm 05.74$ & 0.02 \\
PRAb & $45.59 \pm 06.15$ & $48.69 \pm 12.16$ & 0.14 \\
PLAb & $44.20 \pm 07.19$ & $43.77 \pm 10.68$ & 0.83 \\
ARF & $76.29 \pm 09.32$ & $79.23 \pm 10.58$ & 0.21 \\
ALF & $81.27 \pm 08.24$ & $79.69 \pm 09.53$ & 0.45 \\
AREX & $12.69 \pm 03.28$ & $14.00 \pm 04.93$ & 0.17 \\
ALEX & $11.55 \pm 03.45$ & $13.69 \pm 05.56$ & 0.04 \\
ARAb & $38.24 \pm 07.86$ & $41.31 \pm 09.29$ & 0.13 \\
ALAb & $31.02 \pm 07.59$ & $39.15 \pm 10.23$ & 0.94 \\
A & & &
\end{tabular}

*Statistically significant in the Student's t-test; MR: medial rotation; LR: lateral rotation; Ab: abduction; F: flection; Ex: extension; P: passive; A: active; R: right; L: left; CG: control group; EG: Study group

for passive and active movements of abduction, flexion, and extension; the $\mathrm{CG}$ presented the highest values of range of motion.

These findings may be explained by the presupposition that, during the period of motor learning, these children experiment stimuli to reach lower levels in comparison to a situation in which they would not have visual impairment. Another possibility would be the delay to acquire cephalic stabilization, even if not completely, thus interfering in the modulation of reflexes in childhood and making it difficult to stabilize the cinguli ${ }^{25}$, therefore affecting the use of limbs. These findings are also in contrast with the hypothesis that institutions would be a source of error in the inferences of this study.

The intra-rater correlation index demonstrated that, for most measurements, correlation was moderate.

\section{CONCLUSION}

This study shows that children with congenital low vision have higher ranges of motion for medial shoulder rotations, both in the passive and the active forms of motion, besides the higher mobility in the passive 
medial and lateral hip rotations. These findings point out to a new focus concerning training programs for motor skills and preventive interventions among children with low vision.

\section{REFERENCES}

1. Gianini RJ, Masi Ed, Coelho EC, Oréfice FR, Moraes RA. Prevalence of low visual acuity in public school's students from Brazil. Rev Saude Publica. 2004;38(2);201-8.

2. Bouchard D, Tetreault S. The Motor development of sighted children and children with moderate low vision aged 8-13. J Visual Impair Blin 2000;98(9):564-73.

3. Gilbert C, Foster A. Blindness in children: control priorities and research opportunities. Br J Ophthalmol. 2001;85(9):1025-27.

4. Evensen KA, Lindqvist S, Indredavik MS, Skranes J, Brubakk AM, Vik T. Do visual impairments affect risk of motor problems in preterm and term low birth weight adolescents? Eur J Paediatr Neurol. 2009:13(1):47-56.

5. Zebrowska A, Gawlik K, Zwierzchowska A. Spirometric measurements and physical efficiency in children and adolescents with hearing and visual impairments. J Physiol Pharmacol. 2007;58(Pt 2):847-57.

6. Singh R, Singh HJ. Anthropometric and physiological profiles of active blind malaysian males. J Sports Med Phys Fitness. 1993;33(4):378-82.

7. Horvat M, Nocera J, Ray C, Croce R. Comparison of isokinetic peak force and power in adults with partial and total blindness. Percept Mot Skills. 2006:103(1):231-7

8. Brito PR, Veitzman S. Causas de cegueira e baixa visão em crianças. Arq Bras Oftalmol. 2000;63(1):49-54.

9. Haddad MAO. Habilitação e reabilitação de escolares com baixa visão: aspectos médico-sociais [Tese]. São Paulo: Universidade de São Paulo; 2006. 169p.

10. Catanzariti JF, Salomez E, Bruandet JM, Thevenon A. visual deficiency and scoliosis. Spine (Phila Pa 1976). 2001:26(1):48-52.
11. Aulisa L, Bertolini C, Piantelli S, Piazzini DB. Axial deviations of the spine in blind children. Ital J Orthop Traumatol. 1986;12(1):85-92.

12. Schmid M, Nardone A, De Nunzio AM, Schmid M, Schieppati M. Equilibrium during static and dynamic tasks in blind subjects: no evidence of cross-modal plasticity. Brain. 2007:130(Pt 8):2097-107.

13. Logan D, Kiemel T, Dominici N, Cappellini G, Ivanenko Y, Lacquanit F, et al. The many roles of vision during walking. Exp Brain Res. 2010;206(3):337-50.

14. Asher C. Variações na postura da criança. 1a ed. São Paulo: Manole; 1976.

15. Reimer AM, Cox RF, Nijhuis-Van der Sanden MW, Boonstra FN. Improvement of fine motor skills in children with visual impairment: An explorative study. Research in Developmental Disabilities. 2011;32(5):1924-33

16. Murray KJ, Woo P. Benign joint hypermobility in childhood. Rheumatology. 2001:40(5):489-91.

17. Moura e Castro J, Costa O, de Freitas F. Evaluation of the aerobic capacity of blind people, by direct vo2 maximal measurement. Rev Port Cardiol. 1992:11(6):525-9.

18. Kussuki MOM, João SMA, Cunha ACP. Caracterização postural da coluna de crianças obesas de 7 a 10 anos. Fisioter Mov. 2007;20(1):77-84.

19. Marques AP. Manual de Goniometria. 2a ed. Barueri: Manole; 2003.

20. Domholdt E. Physical Therapy Research. Philadelphia: W.B. Saunden Company; 1993

21. Jonson SR, Gross MT. Intraexaminer Reliability, Interexaminer Reliability, and Mean Values for Nine Lower extremity Skeletal measures in healthy naval midshipmen. J Orthop Sports Phys Ther. 1997:25(4):253-63.

22. Wahlund K, List T, Dworkin SF. Temporomandibular disorders in children and adolescents: reliability of a questionnaire, clinical examination, and diagnosis. J Orofac Pain. 1998:12(1):42-51.

23. Thinus-Blanc C, Gaunet F. Representation of space in blind persons: vision as a spatial sense? Psychol Bull. 1997;121(1):20-42.

24. Gaunet F, Martinez JL, Thinus-Blanc C. Early-blind subjects' spatial representation of manipulatory space: exploratory strategies and reaction to change. Perception. 1997;26(3):345-66.

25. Shumway-Cook A, Woollacott MH. Controle Motor. Teoria e aplicações práticas. $2^{\mathrm{a}}$ ed. São Paulo: Manole; 2003. 